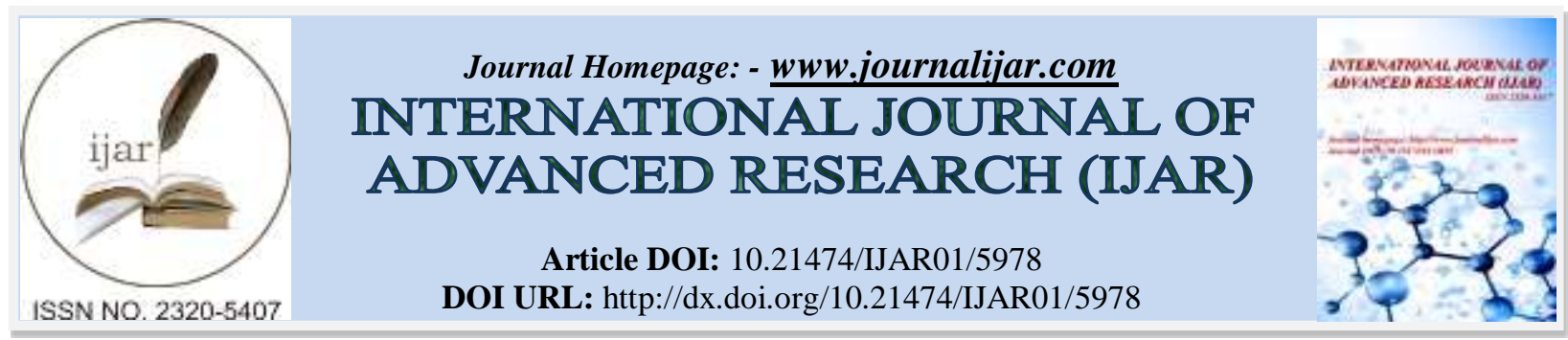

RESEARCH ARTICLE

\title{
THE BIOLOGICAL COMPLICATION OF IMPLANT ABUTMENT MATERIALS.
}

Mohamed M.Radwan ${ }^{1}$,Mohamed A.Mokhtar ${ }^{2}$, Gihan Elnagar $^{3}$ and Maged Saleh ${ }^{4}$,

1. Lecture, Department of fixed prosthodontics, faculty of dentistry, Beni-suef University, Eygpt.

2. Lecture, Department of fixed prosthodontics, faculty of dentistry, MSA University, Eygpt.

3. Professor, Department of fixed prosthodontics, faculty of dentistry, Cairo University, Eypt.

4. Lecture, Department of fixed prosthodontics, Faculty of Oral and Dental Medicine, Hodeidah University, Yemen.

\section{Manuscript Info}

Manuscript History

Received: 05 October 2017

Final Accepted: 07 November 2017

Published: December 2017

Key words:-

Implant abutments, pocket depth, recession, crestal bone loss, titanium, zirconia

\section{Abstract}

Objectives: The goal of this review was to identify the biological complication of implant abutment materials in relative to alveolar bone around implant supported superstructure. Methodology: An electronic database search and further a manual searching was directed to detect RCTs, and cohort studies that give evidence about different abutment materials complication. Pocket depth, amount of rescission and crestal bone loss were attributed to alveolar bone loss. Results: fourteen clinical studies were detected from an initial search of 107 studies and the extraction of the analyzing data were tabled according to complication output. Pocket probing depth were documented in eight studies, PPD around Zirconium implant abutments was $3.2 \mathrm{~mm}$ versus $3.4 \mathrm{~mm}$ for Titanium abutment. Five studies examined the recession index for Zirconium and Titanium implant abutments. The RI ranged from 0 to 0.4 at Titanium implant abutments and 0 to 0.3 at Zirconium implant abutments. For the alveolar loss around Zirconia implant abutment was stated to differ from $0.2-1.48$ and $0.3-1.43 \mathrm{~mm}$ at Titanium abutments. Conclusion: The data reported in this systematic review did not give an evidence for the complication regarding all ceramic versus metallic implant abutment. However, it can be concluded that the assessment of the randomized clinical trials did not provide an absolute decision for the choice of ceramic or metallic as implant abutment material relative to alveolar bone response. The meta-analysis presented a statistically significant difference between abutment material with superiority for the all ceramic abutments over metallic abutment providing a favorable response of Marginal Bone Loss, but with non- statistically significant regarding Pocket Probing Depth (PPD) and Recession Index of soft tissue (RI)

Copy Right, IJAR, 2017,. All rights reserved

\section{Introduction:-}

Implant supported restorations are presently an expectable method, which, in some cases is chosen to be more conventional substitutes to removable or fixed prostheses (1). polycrystalline ceramics alumina or zirconia 
abutment were used in high esthetic region as an ancillary for metallic abutment (2). In a recent clinical study, In different esthetics situation the zirconium abutment shows high documented performance over titanium abutments (3). brittleness is still the limitation of ceramic materials (4). This property for all ceramic material decrease the resistance to tensile forces. The all ceramic material has high tensile forces which increase the fracture risk of the material for a during function. Whether the fracture toughness of the ceramic is the main cause of fracture (5). zirconia shows the uppermost fracture toughness among all dental ceramics (1). Clinical studies show that supported prosthesis either on teeth supported or on implants supported can be constructed from zirconium frameworks give high clinical performance on function. In the esthetic area after four years of follow up, zirconium implant abutment shows no evidence of fractures $(6,7)$. On the other side, the alumina abutments after 1 year shows $7 \%$ fracture of the alumina abutment (8).

Peri-implant alveolar bone loss determined through routine radiographically. which defined as a localized inflammatory lesion relating to alveolar bone loss round to a completely osseointegrated implant supported restoration (9). after at least 10 years of functional loading, many studies have been published (2000-2017) observing survival rates of implant supported restoration and concluded that the mean survival rate ranged from $87 \%$ to $96 \%$. Implant supported restoration are overwhelmed with biological and mechanical complications despite having high long-term survival rates. (10). The cause of Crestal bone loss may be due to mechanical or biological factors. The common mechanical complication that results from poor prosthetic design, insufficient number of implant, size and position of implant fixture and parafunctional habits of patients is occlusal overloading(11). The clinical drawbacks of inaccurate implant supported restoration range from fractures of abutment screws, prostheses losing, implant fracture and periimplant "marginal bone loss". The main biological cause of alveolar bone loss is microbial pathogens in dental plaque (12).

\section{Aim of Research:-}

The goal of this review was to detect the complication of different abutment (all ceramic and metallic) materials of the implant supported restoration regarding the biological complication.

\section{Methods:-}

\section{Criteria of studies :-}

\section{Article types:-}

All randomized controlled trials (RCTs) \& cohort study estimating the effect of different types of implant abutment (metallic or all ceramic abutment) on the alveolar bone loss of implant supported superstructure.

\section{The participante:-}

People having implant supported restoration affected by bone loss.

\section{The interventions:-}

All types of implant abutment (metallic or all ceramic abutments)

\section{Outcomes :-}

1. Alveolar bone loss, signs attributing for alveolar bone loss

2. Radiographic by intraoral radiographs.

3. Pocket depth (PD).

Soft tissue recession (REC) .

\section{Search methods for identification of studies:- Electronic databases searches:-}

The resulting inclusion criteria (table 1) were obligatory to: complication of implant supported restoration (biological complication), articles published in English. Case report, case study, invitro study, article in press and animal studies articles were excluded (table2).

To identify the research question, the PubMed database, the Cochrane and ovoid databases were searched electronically. Databases were searched for articles from 2000 through October 2017 using the next (MeSH) terms: (a) dental abutment (b) implants abutment (c) zirconia abutment (d) All ceramic abutment (e) metallic abutment (f)titanium abutment (g) periodontal loss (h) periodontal pocket (i) periodontal pocket index, (j) alveolar bone loss 
(k) rescission and the combinations. Other applicable non-MeSH words were used in the search to recognize articles showing periodontal inflammatory parameters. These included "yettriastabilized zirconia abutment" "zirconia implant abutment" "inflammation implant abutment" "bleeding index implant abutment" and "periimplant pocket" and "clinical attachment loss around implant abutment." The studies collected after the described protocol were assessed by 3 authors (M.M., J.E., M.A.). The studies full texts were read by authors (M.M., M.S, J.E.) and independently assessed according to the inclusion criteria. For more deep knowledge hand search was done in the reference lists studies included during primary research. The contents of some nominated journals were independently searched by 2 authors (M.M.,J.E.) for related studies available up to october 2017 . This was performed to detect any studies which may be lost in the earlier step. The included studies were checked among the all authors for any divergence.

\section{Data collection and analysis:-}

\section{Study selection:-}

The 107 articles were screened independently by two reviewer (M.M., J.E.) through titles and abstracts. articles that meet the inclusion criteria and that have no sufficient data to take optimum choice, the full text was gotten. The full reports that are collected from the different electronic and hand searching were checked independently by two authors(M.M.,M.A.) to get an absolute decision of whether these articles met the inclusion criteria or not.

Disagreements were resolved among authors by open discussion; where a third review author (M.S) was a consulted and firmness was not possible, 14 studies meet the inclusion criteria, data extraction were done under constant protocol. Studies rejected at this stage or following stages were collected. A table for the excluded studies and the reasons for exclusion was reported.(table 3).

\section{Data extraction:-}

Independently using constant designed data extraction forms fourteen studies undergo data extraction by two review authors (M.M.,J.E.) . Data extraction were shown and modified on several papers before agreement to use. Any disagreement among author were debated in open discussion and a review author(M.S.) consulted was essential. Data of disagreement were excluded until clarification was presented.

For each study, the extracted data was listed as follow (table 4).

1. Year of publication.

2. The participants (No., Sex, Age)

3. The type of intervention (No., Types)

4. The outcomes reported. (No., Assessment method)

\section{Missing data Protocol :-}

Efforts was done to regain missing data from trials authors. and if cross-sectional data were accessible; Change data can be done, the standard deviation "SD" of the changes was to be assessed using the no. within patient correlation, which will give information to the conservative estimate of the SD for change. This technique was described by Follmann (13). To guess the standard error of the difference for split mouth studies, when the proper data were not accessible and could not be found.

\section{Heterogeneity Assessment :-}

Cochran's test for heterogeneity was used to assess the significance of any differences. heterogeneity would have been considered significant if $\mathrm{P}<0.1$. All 14 included studies results were pooled using the random model effect as statistical heterogeneity among studies was significance where (I4 $=93 \% \mathrm{P}<0.00001)$.

\section{Results:-}

After inclusion criteria regulation, fourteen studies were selected, Included studies tested customized metallic and all ceramic abutments and also provided data on standard all ceramic and metallic abutments (14-17). All included studies reported a well-defined period of follow-up.

\section{Meta-analysis:-}

Results of the Outcome of all ceramic and metallic abutments on Radiographic Marginal Bone Loss (MBL):Marginal bone level 14 studies (table 4) reported on interproximal marginal bone-lose. Mean bone loss differ from 0.20-0.40 to $1.05-1.48 \mathrm{~mm}$ for zirconia abutments and 0.3-0.5 to $0.67-1.43 \mathrm{~mm}$ for titanium abutments. Distal and mesial marginal bone loss was stated by some papers. The meta-analysis was done to evaluate the same intervention 
and outcomes for the fourteen included studies. The mean difference for the unceasing outcome (MBL)was used, using a software program of random effect model (RevMan 5.3, 2014).

\section{Assessment of heterogeneity:-}

any discrepancies in the treatment effects estimation from the different RCTs will be evaluated by the means of Cochran's test for heterogeneity and heterogeneity, which will have considered significant if $\mathrm{P}<0.1$. The 14 statistic, which will describes the percentage of the total difference across the trials that is due to heterogeneity other than chance, will be used to compute heterogeneity with 14 over $50 \%$ being considered moderate to high heterogeneity. All 10 included studies results were pooled using the random model effect as statistical heterogeneity among studies was significance where $(\mathrm{I} 4=93 \% \mathrm{P}<0.00001)$. The mean difference of MBL which used in this meta-analysis the mean difference of marginal bone loss between all ceramic and titanium abutments for all pooled results were $-0.20(-0.32-0.08)$ with $95 \%$ confidence interval. This overall estimate is statistically significant with $\mathrm{P}$ $<0.0009$. The meta-analysis was done for the continuous outcome with random effect model, as seen in (Fig. 2).

Results of the Effect of metallic and nonmetallic implant abutment on Pocket Probing Depth (PPD):eight studies recorded the pocket probing depth. Albornoz et al.(12) measured six pocket probing depth sites while the other seven papers measured pocket depth at four sites. After one-year follow-up, $(12,15)$ reported the mean pocket depth around Titanium abutments was $3.3 \mathrm{~mm}$ while mean pocket depth around all ceramic zirconia abutments was from 2.90 to $3.50 \mathrm{~mm}$, de Alboroz et al. (12) reported that after one-year of follow-up an rise of 0.2 from baseline was recorded around Zirconia abutments, while pocket probing depth around Titanium abutments remained unaffected. Recently (16) the mean pocket depth around Zirconia abutments was 3.38mm, while the mean pocket depth around metallic abutments was $3.3 \mathrm{~mm}$ (16). after 3-year follow-up, zirconia abutment shows pocket probing depth of $3.2 \mathrm{~mm}$ versus $3.4 \mathrm{~mm}$ at the sites of titanium abutment (18). The survival rate after 5 years was applied by several studies. Zembic et al. (19) stated that the mean pocket probing depth around Zirconia abutments of 3.3 with an upsurge of $0.4 \mathrm{~mm}$ from the baseline, while Titanium abutments had an increase from the baseline by $0.5 \mathrm{~mm}$. Lops et al. (10) stated 2.6 for Zirconia abutments and $2.7 \mathrm{~mm}$ for Titanium sites. No significant differences was informed between Zirconia and Titanium abutments in the included studies. The pocket probing depth mean difference which used in this meta-analysis were $-0.10(-0.25-0.05)$ with $95 \%$ confidence interval. This overall evaluation is non-significant statistically with $P=0.18$. The meta-analysis with random effect model was made for the continuous outcome as seen in( Fig. 3)

\section{Results of the Effect of metallic and nonmetallic implant abutment on rescission index :-}

Examination of rescission index around Zirconia and Titanium abutments was reported in four studies. showing mean values at Zirconia abutments ranged from 0 to 0.3 and at Titanium abutments ranged from 0 to 0.4 , after 6 months the mean of recession index around Zirconia abutment was 0.16 while for titanium abutment was 0.27 (15).later 1 year follow up the mean of recession index around Zirconia abutment was zero while for titanium abutment was 0.04 (12), furthermore increasing the recession was reported after 2 year follow up for Zirconia to range from 0.3 and was 0.4 for titanium abutment (10), additionally the mean of recession index around Zirconia abutment ranged from 0.1-0.3 whereas for titanium abutment was from 0.3- 0.4 after $3 y$ and 5y follow up (8,11) with no significant differences between them .

The mean difference of rescission index was $-0.09(-0.20-0.03)$ with $95 \%$ confidence interval. This overall estimate is statistically non-significant with $P=0.13$. The meta-analysis with random effect model was made for the continuous outcome of rescission index as seen in (Fig. 4)

Table (1):- Inclusion criteria

Inclusion criteria

- Clinical studies compare all ceramic to metallic abutments

- Studies of 10 sample size at least

- Studies at least show one of the outcome.

- Studies in English

Table (2):- Exclusion criteria

Exclusion criteria

Unc0ntr0lled randomized clinical trial 


\begin{tabular}{|l|}
\hline studies of retrospective clinical trial \\
\hline randomized clinical trial using teeth as control group \\
\hline Review ( systematic or ordinary) \\
\hline experimental (animal) studies \\
\hline case-reports \\
\hline unpublished articles \\
\hline
\end{tabular}

Table (3):- Studies excluded from this review

\begin{tabular}{|l|l|}
\hline Author /year & Reason for exclusion \\
\hline Belser et al. 2004 & Review article \\
\hline Bragger et al.2005 & Titanium abutment only \\
\hline Buchi et al. 2014 & Zirconia abutment only \\
\hline Canullo et al.2007 & Zirconia abutment only \\
\hline De boever et al 2006 & Titanium abutment only \\
\hline Ekfeldt et al.2011 & Zirconia abutment only \\
\hline Glauser et al. 2004 & Zirconia abutment only \\
\hline Muche et al.2003 & Titanium abutment only \\
\hline Nakamura et al. 2010 & Zirconia abutment only \\
\hline Passos et al.2014 & Zirconia abutment only \\
\hline Pjetursson, et al 2004 & Systematic review \\
\hline Sailer et al. 2009 & Systematic review \\
\hline Vigolo et al. 2006 & Metallic abutment only \\
\hline Zembic et al. (2014a) & Teeth as control group \\
\hline
\end{tabular}

Table(4):- Effect Of Bone Loss In The Included Stydies

\begin{tabular}{|c|c|c|c|c|c|c|c|c|}
\hline Study & year & $\begin{array}{l}\text { Study } \\
\text { design }\end{array}$ & $\begin{array}{l}\text { No.of } \\
\text { patient }\end{array}$ & $\begin{array}{l}\text { Follow } \\
\text { up }\end{array}$ & $\begin{array}{l}\text { Total no. } \\
\text { of } \\
\text { abutment }\end{array}$ & $\begin{array}{l}\text { Titanium } \\
\text { abutment }\end{array}$ & $\begin{array}{c}\text { All } \\
\text { ceramic } \\
\text { abutment }\end{array}$ & "bone loss mean (SD)mm" \\
\hline $\begin{array}{l}\text { Andersson } \\
\text { et al. }\end{array}$ & 2001 & RCT & 15 & $1 y-3 y$ & 69 & 35 & 34 & NA \\
\hline $\begin{array}{l}\text { Andersson } \\
\text { et al. }\end{array}$ & 2003 & $\mathrm{RCT}$ & 32 & $5 y$ & 103 & 50 & 53 & $\begin{array}{l}0.3(0.2) \mathrm{mm} \text { ceramic and } 0.4 \\
(0.3) \mathrm{mm} \text { titanium }\end{array}$ \\
\hline $\begin{array}{l}\text { Zembic et } \\
\text { al. }\end{array}$ & 2009 & RCT & 22 & $3 y$ & 28 & 10 & 18 & NA \\
\hline Sailer et al & 2009 & RCT & 20 & $1 \mathrm{y}$ & 31 & 12 & 19 & NA \\
\hline Ralph et al. & 2010 & RCT & 20 & $3 \mathrm{~m}$ & 40 & 20 & 20 & $\begin{array}{l}1.7(0.7) \mathrm{mm} \text { ceramic and } 2.2 \\
(0.8) \mathrm{mm} \text { titanium }\end{array}$ \\
\hline $\begin{array}{l}\text { Hosseini et } \\
\text { al. }\end{array}$ & 2011 & RCT & 31 & $1 \mathrm{y}$ & 72 & 34 & 38 & $\begin{array}{l}0.08(0.17) \mathrm{mm} \text { ceramic and } \\
(0.25) 0.1 \mathrm{~mm} \text { titanium }\end{array}$ \\
\hline $\begin{array}{l}\text { Zembic et } \\
\text { al. }\end{array}$ & 2013 & RCT & 18 & $5 y$ & 28 & 10 & 18 & $\begin{array}{l}0.5(0.5) \mathrm{mm} \text { ceramic and } 0.8 \\
(0.7) \mathrm{mm} \text { titanium }\end{array}$ \\
\hline $\begin{array}{l}\text { Hosseini et } \\
\text { al. }\end{array}$ & 2013 & CCT & 59 & $3 y$ & 73 & 21 & 52 & $\begin{array}{l}0.15(0.25) \mathrm{mm} \text { ceramic and } \\
0.18(0.29) \mathrm{mm} \text { titanium }\end{array}$ \\
\hline Lops et al. & 2013 & CCT & 81 & $5 y$ & 81 & 45 & 36 & $\begin{array}{l}0.4(0.1) \mathrm{mm} \text { ceramic and } \\
0.5(0.1) \mathrm{mm} \text { titanium }\end{array}$ \\
\hline $\begin{array}{l}\text { de Alboroz } \\
\text { et al. }\end{array}$ & 2014 & CCT & 25 & $1 \mathrm{y}$ & 25 & 14 & 11 & $\begin{array}{l}0.06(0.07) \mathrm{mm} \text { ceramic and } \\
0.45(0.02) \mathrm{mm} \text { titanium }\end{array}$ \\
\hline Lops et al. & 2015 & PCT & 72 & $2 y$ & 72 & 39 & 33 & $\begin{array}{l}0.1(0.1) \mathrm{mm} \text { ceramic and } \\
0.3(0.2) \mathrm{mm} \text { titanium }\end{array}$ \\
\hline Payer et al. & 2015 & RCT & 30 & $2 \mathrm{Y}$ & 30 & 15 & 15 & $\begin{array}{l}0.1(0.19) \mathrm{mm} \text { ceramic and } \\
0.16(0.24) \mathrm{mm} \text { titanium }\end{array}$ \\
\hline Nascimento & 2016 & RCT & 20 & $6 \mathrm{~m}$ & 20 & 10 & 10 & $0.92(0.36) \mathrm{mm}$ ceramic and \\
\hline
\end{tabular}




\begin{tabular}{|c|c|c|c|c|c|c|c|l|}
\hline et al. & & & & & & & & $1.25(0.27) \mathrm{mm}$ titanium \\
\hline $\begin{array}{c}\text { Yogesh et } \\
\text { al. }\end{array}$ & 2017 & RCT & 12 & $1 \mathrm{y}$ & 12 & 12 & 12 & $\begin{array}{l}0.5(0.50) \mathrm{mm} \text { ceramic and } \\
1.53(0.53) \mathrm{mm} \text { titanium }\end{array}$ \\
\hline
\end{tabular}

Table (5):- The effect of zirconia and titanium on biological complication

\begin{tabular}{|c|c|c|c|c|c|c|c|c|c|c|}
\hline \multirow[t]{2}{*}{ study } & \multirow[t]{2}{*}{ Year } & \multirow[t]{2}{*}{$\begin{array}{l}\text { Follow } \\
\text { up }\end{array}$} & \multirow{2}{*}{$\begin{array}{l}\text { Total no. } \\
\text { of } \\
\text { abutment }\end{array}$} & \multirow[t]{2}{*}{$\begin{array}{l}\text { Titanium } \\
\text { abutment }\end{array}$} & \multirow{2}{*}{$\begin{array}{c}\text { All } \\
\text { ceramic } \\
\text { abutment }\end{array}$} & \multirow{2}{*}{$\begin{array}{l}\text { Bone level } \\
\text { loss } \\
\text { measuring } \\
\text { method }\end{array}$} & \multicolumn{2}{|c|}{$\begin{array}{l}\text { recession } \\
\text { index }\end{array}$} & \multicolumn{2}{|c|}{ Pocket depth } \\
\hline & & & & & & & zir & tit & zir & tit \\
\hline $\begin{array}{l}\text { Andersson et } \\
\text { al. }\end{array}$ & 2001 & $1 y-3 y$ & 69 & 35 & 34 & periapical & 0.3 & 0.4 & & \\
\hline $\begin{array}{l}\text { Andersson et } \\
\text { al. }\end{array}$ & 2003 & $5 y$ & 103 & 50 & 53 & $\begin{array}{l}\text { Periodontal } \\
\text { probe }\end{array}$ & & & & \\
\hline $\begin{array}{l}\text { Zembic } \\
\text { et al. }\end{array}$ & 2009 & $3 y$ & 28 & 10 & 18 & Periapical & & & $\begin{array}{l}3.2 \\
(1)\end{array}$ & $\begin{array}{c}3.4 \\
(0.5)\end{array}$ \\
\hline $\begin{array}{c}\text { Sailer } \\
\text { etal }\end{array}$ & 2009 & $1 y$ & 31 & 12 & 19 & $\begin{array}{c}\text { Orthoradial } \\
\text { Ro }\end{array}$ & & & $\begin{array}{c}3.5 \\
(0.7)\end{array}$ & $\begin{array}{c}3.3 \\
(0.6)\end{array}$ \\
\hline Ralph et al. & 2010 & $3 \mathrm{~m}$ & 40 & 20 & 20 & $\begin{array}{l}\text { Periodontal } \\
\text { probe }\end{array}$ & $\begin{array}{c}2.7 \\
(0.6)\end{array}$ & $\begin{array}{l}2.6 \\
(1)\end{array}$ & $\begin{array}{l}1.7 \\
(0.7)\end{array}$ & $\begin{array}{c}2.2 \\
(0.8)\end{array}$ \\
\hline $\begin{array}{l}\text { Hosseini } \\
\text { et al. }\end{array}$ & 2011 & $1 \mathrm{y}$ & 72 & 34 & 38 & Periapical & & & & \\
\hline $\begin{array}{l}\text { Zembic } \\
\text { et al. }\end{array}$ & 2013 & $5 y$ & 28 & 10 & 18 & $\begin{array}{c}\text { Orthoradial } \\
\text { Ro }\end{array}$ & $\begin{array}{l}0.1 \\
(1)\end{array}$ & $\begin{array}{c}0.3 \\
(0.7)\end{array}$ & $\begin{array}{c}3.3 \\
(0.6)\end{array}$ & $\begin{array}{c}3.6 \\
(1.1)\end{array}$ \\
\hline $\begin{array}{l}\text { Hosseini } \\
\text { et al. }\end{array}$ & 2013 & $3 y$ & 73 & 21 & 52 & periapical & & & & \\
\hline Lops et al. & 2013 & $5 y$ & 81 & 45 & 36 & Periapical & & & $\begin{array}{c}2.6 \\
(0.5)\end{array}$ & $\begin{array}{c}2.7 \\
(0.4)\end{array}$ \\
\hline $\begin{array}{l}\text { de Alboroz } \\
\text { et al. }\end{array}$ & 2014 & $1 \mathrm{y}$ & 25 & 14 & 11 & Periapical & $\begin{array}{c}\text { REC } \\
0(0\end{array}$ & $\begin{array}{l}0.04 \\
(0.1\end{array}$ & $\begin{array}{l}2.9 \\
(0.5\end{array}$ & $\begin{array}{c}3.3 \\
(0.8)\end{array}$ \\
\hline Lops et al. & 2014 & $2 y$ & 72 & 39 & 33 & Periapical & $\begin{array}{c}0.1 \\
(0.3)\end{array}$ & $\begin{array}{c}0.3 \\
(0.4)\end{array}$ & & \\
\hline Payer et al. & 2015 & $2 \mathrm{Y}$ & 30 & 15 & 15 & Periapical & & & & \\
\hline $\begin{array}{l}\text { Nascimento } \\
\text { et al. }\end{array}$ & 2016 & $6 \mathrm{~m}$ & RCT & 10 & 10 & $\begin{array}{l}\text { Periodontal } \\
\text { probe }\end{array}$ & $\begin{array}{c}0.16 \\
\pm \\
0.42\end{array}$ & $\begin{array}{l}0.27 \pm \\
0.60\end{array}$ & $\begin{array}{c}2.12 \\
\pm 0.70\end{array}$ & $\begin{array}{c}2.05 \pm \\
0.87\end{array}$ \\
\hline Yogesh et al. & 2017 & $1 \mathrm{y}$ & RPS & 12 & & periapical & & & $\begin{array}{c}3.29 \\
\pm 0.50\end{array}$ & $\begin{array}{c}3.38 \\
\pm 0.53\end{array}$ \\
\hline
\end{tabular}

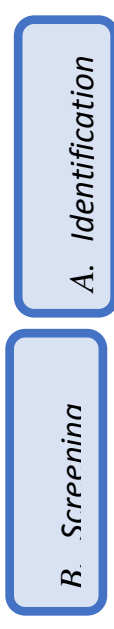

Figure (1):- Overview of the search strategy.

First electronic search \& free hand searching by 3 reviewers

$$
\text { ( } n=107 \text { ) }
$$

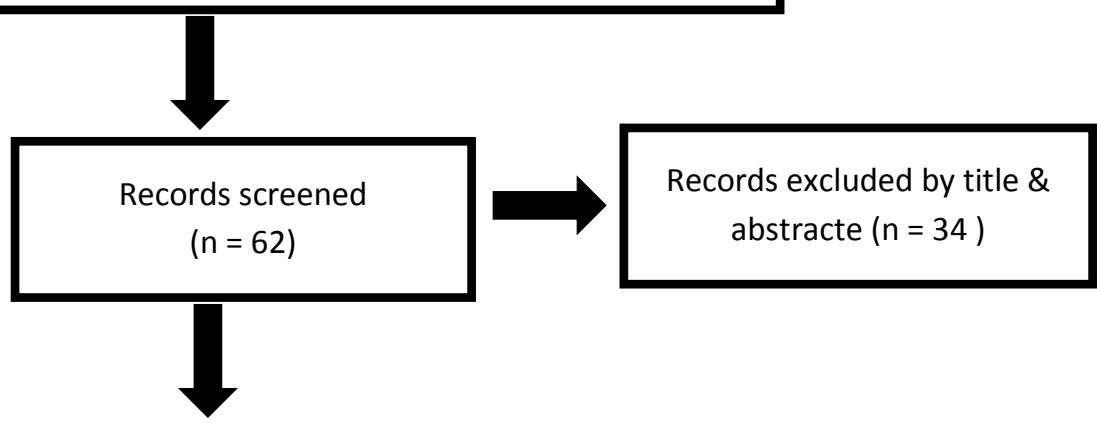



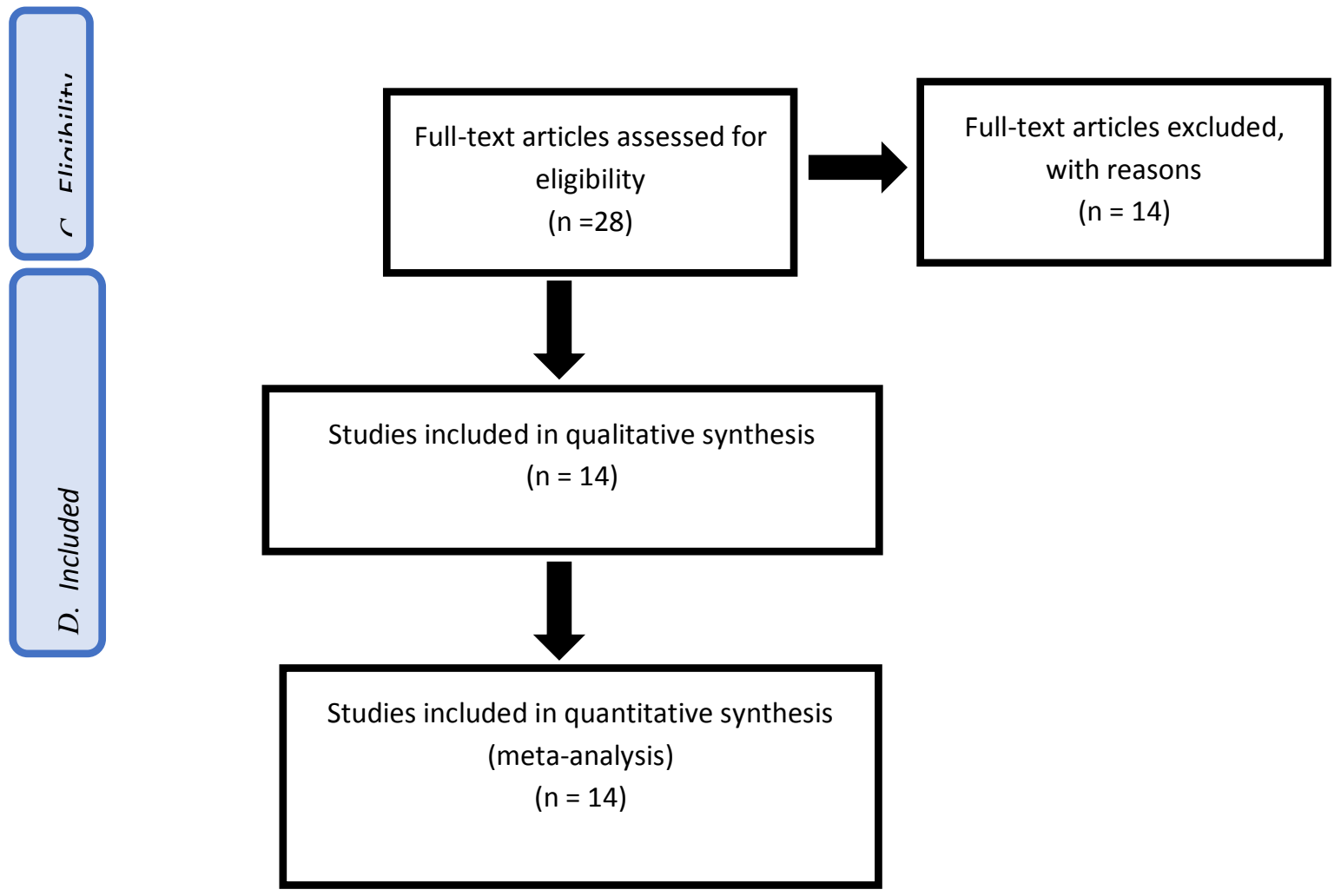

Figure(2):- Forest plot of comparison implants all ceramic zirconia abutments versus Ti abutments, outcome: Marginal BoneLoss (mm)

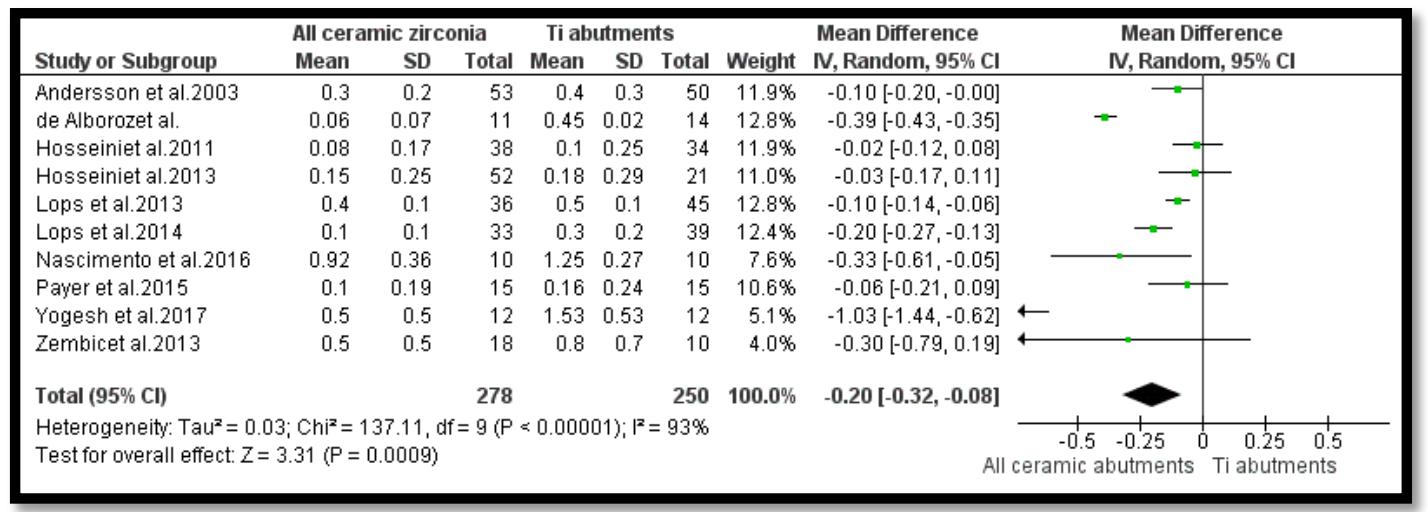


Figure (3):- Forest plot of comparison implants all ceramic zirconia abutments versus Titanium abutments, outcome: Pocket Probing Depth (mm)

\begin{tabular}{|c|c|c|c|c|c|c|c|c|c|}
\hline \multirow[b]{2}{*}{ Study of Subuteup } & \multicolumn{3}{|c|}{ All ceramic zirconia } & \multicolumn{3}{|c|}{ Ti abufments } & \multirow[b]{2}{*}{ Weight } & \multirow{2}{*}{$\begin{array}{l}\text { Mean Difference } \\
\text { N. Random, } 95 \% \mathrm{Cl}\end{array}$} & \multirow{2}{*}{$\begin{array}{l}\text { Mean Difference } \\
\text { N. Random } 995 \mathrm{Cl}\end{array}$} \\
\hline & Mean & SD & Totad & Mean & SD & Total & & & \\
\hline de Aborceet al. & 0.02 & 0.1 & 11 & 0.04 & 0.1 & 14 & $60.3 \%$ & $-0.02\lceil-0.10,0.06\}$ & \\
\hline Lops et al.2014 & 0.1 & 0.3 & 33 & 0.3 & 0.4 & 39 & $30.9 \%$ & $-0.20[-0.36,-0.04]$ & \\
\hline Nascimento et al 2016 & 0.16 & 0.42 & 10 & 0.27 & 0.6 & 10 & $5.7 \%$ & $-0.11[-0.56,0.34]$ & \\
\hline Zembicet al.2013 & 0.1 & 1 & 18 & 0.3 & 0.7 & 10 & $3.0 \%$ & $-0.20+-0.83,0.43 \mid$ & \\
\hline Tota $(95 \% \mathrm{Cl})$ & & & 72 & & & 73 & $100.0^{2}$ & $-0.09[-0.20,0.03]$ & \\
\hline \multicolumn{9}{|c|}{$\begin{array}{l}\text { Heterogeneity: Tau }=0.00, \mathrm{Ch}^{\mathrm{N}}=4.09, \mathrm{df}=3(\mathrm{P}=0.25), \mathrm{I}^{\mathrm{x}}=2 \mathrm{~T} \% \\
\text { Test for oreral effect } \mathrm{Z}=1.50 \mathrm{P}=0.13)\end{array}$} & $\begin{array}{cccc}-1 & -0.5 & 0 & 0.5\end{array}$ \\
\hline
\end{tabular}

Figure (4):- Forest plot of comparison implants all ceramic zirconia abutments versus Titanium abutments, outcome: Recession Index (mm)

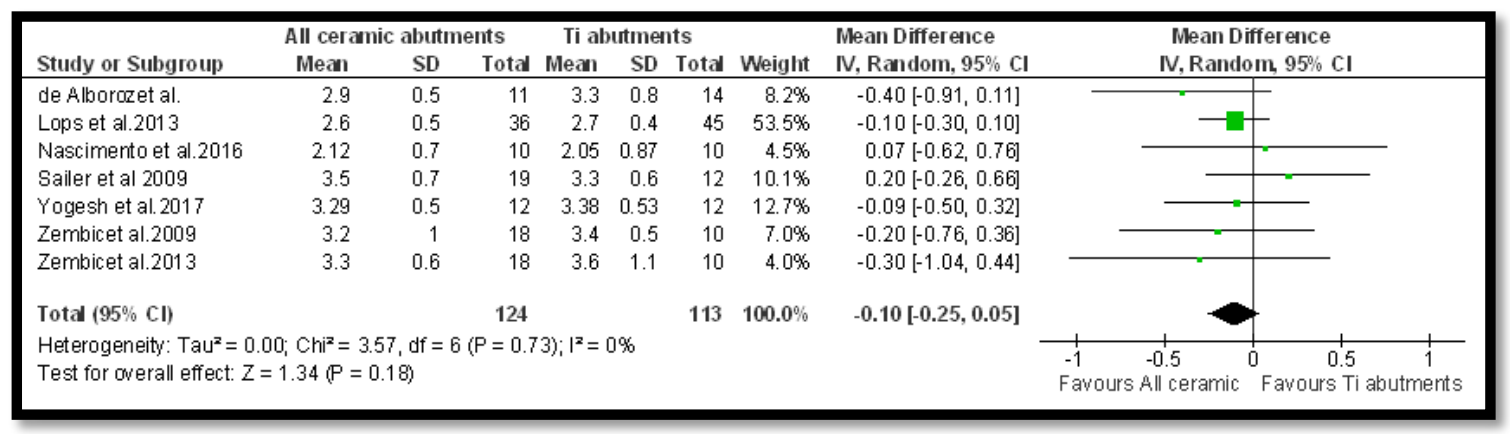

\section{Discussion:-}

The purpose of this review was to systematically assess the biological complication all ceramic and metallic abutments. The authors in their investigation focused on the biological outcome (pocket depth and recession) . The authors plan was to exclude studies in which abutments were compared to tooth born restoration or any restoration other than implant abutment. So, follow-up ranged from four to eleven years were omitted in several studies $(6,11)$. This action can be claimed; though, patient bias is avoidable through uncontrolled prospective clinical trials. Therefore, the longest follow-up included was 5 years long $(10,11)$. In general, the results of both abutment materials showed only minor statistically significant differences. Evidence-based review assessed the outcome of abutment materials on alveolar bone loss, was drawn in the same decision as previous, (27). Based on visceral, human biology and different clinical studies, abutments materials (zirconia \& titanium) showed no difference in effect on alveolar bone stability. The present systematic review shows no significant differences on pocket probing depths between the different abutment materials. On the other hand, it is inspiring to note that van Brakel et al. (21) showed significantly lower pocket probing depth around Zirconium abutments compared to Titanium abutment. This study showed a complete picture of the surface roughness zirconia and titanium implant abutments (Ra-val. 210 Zirconia-236 Titanium nm). New invitro studies (15) showed that the surface roughness of the different abutment materials has a significant role in the performance of cells on Zirconia or Titanium abutment. It was stated that polished Zirconia surfaces, in compression to Titanium surface gives a better adhesion media for attachment cells (22). It could be speculated that decrease pocket probing depth around implant abutment is in deep relation with well adherence of the gingival cells to the abutments. it is hard to evaluate the plaque accumulation influence on the abutment material due to abutment aren't showing to oral cavity. The included studies didn't frequent a biological or mechanical complication. The most noticeable complication was noted in two studies $(23,24)$. Remarkably, fistulas triggered by excess cement was documented as one of biological complications, $(25,26)$, So this result was explained by the abutment design. the margin of the superstructure is located subgingival about 1-1.5 mm below gingival crest, implant supported fixed partial denture were cemented using dual cured resin cement on zirconia abutment so due to removal of excess cement which is extremely difficult to be removed as a result biological complication was speculated. So, it is concluded that full removal of excess resin cement is must even if with customized implant abutment. (27). So, it is very difficult to remove an excess of resin cement from the implant abutment (28). Therefore, the idea of this complication is not related to abutment material (titanium or zirconia) but 
in deep dependent to abutment design and cementation agent. Resin cement remnant was documented to be a probable reason for implant loss in on article (11). The microbial variety and microorganisms number in oral biofilm in relation to different abutment materials reported that the titanium abutment have a high concentration of microorganisms numbers and also biofilm mass. Due to roughness of titanium surfaces which play an important role in microbial adhesion. oppositely, zirconia abutment shows the free energy surface which lead to lower susceptibility for bacterial adhesion. Supporting to the idea of biomaterial property's play an important role in stress distribution around implant abutment which in sequence affect the alveolar bone loss (15), suggested that higher elastic of modulus for the implant supported superstructure material allowed for a more uniform stress distribution within the implant supported framework, thus providing a more effective and reliable load transfer to the implant fixture. This could clarify that why the all ceramic restorations (high modulus of elasticity) could redistribute the stresses more evenly to the implant fixture when compared to the other restorations. (29). One of the important approach on clinical practice to preserve the soft tissue integrity and improving the peri-implantitis treatment is decreasing bacterial adhesion and consequently biofilm formation on implant abutment surface. However, Different types of implant abutment materials show different opinion for biofilm formation. Titanium and zirconium abutment show hydrophobic activity due to thick peptidoglycan layer that attract immediately the gram-positive bacteria. In the opposite hand gram-negative bacteria will be fend off. although the hydrophobicity of titanium and zirconium abutment play an important role for bacterial adhesion but the bioactive dioxide layer titanium shows semiconductor structures, and this may explain debated results in the systematic literature(22).

\section{Conclusions:-}

Although until now all evidence based researches doesn't give a absolute-cut decision for the use of ceramic or metallic as abutment materials in relative to alveolar bone response, some studies show better mechanical \& Biological performance of zirconia abutment over titanium abutment. Regarding meta-analysis zirconia abutments gives statistically significant advantage of over titanium one in developing favorable response of alveolar bone

\section{References:-}

1. Siddiqi A, Kieser JA, De Silva RK, Th0mson WM, Duncan WJ. Soft and hard tissue response to zirconia versus titanium one-piece implants placed in alveolar and palatal sites: a randomized control trial. Clin Implant Dent Related Res 2015;17:483-96.

2. Payer, M., Heschl, A., Koller, M., Arnetzl, G., Lorenzoni, M. \& Jakse, N. All-ceramic restoration of zirconia two-piece implants - a randomized controlled clinical trial. Cl. Oral Impl.Res (2015). 26:371-376.

3. Jung, R.E., Holderegger, C., Sailer, I., Khraisat, A., Suter, A. \& Hammerle, C.H. The effect of all-ceramic and porcelain-fused-to-metal restorations on marginal peri-implant soft tissue color: a randomized controlled clinical trial. Int. J. of Pe. \& Rest. Dent. (2008) 28: 357-365.

4. Belser, U.C., Schmid, B., Higginbottom, F. \& Buser, D. Outcome analysis of implant restorations located in the anterior maxilla: a review of the recent literature. Int. J. of Oral \& Max. Implants (2004) 19: 30-42.

5. Anders Ekfeldt, Fürst B, Carlsson GE. Zirconia abutments for single-tooth implant restorations: a retrospective and clinical follow-up study. Clin Oral Implants Res. 2011 Nov;22(11):1308-14.

6. Glauser, R., Sailer, I., Wohlwend, A., Studer, S., Schibli, M. \& Scharer, P. Experimental zirconia abutments for implant-supported singletooth restorations in esthetically demanding regions: 4-year results of a prospective clinical study. The Int. Jour. of Prosth. (2004) 17: 285-290

7. Canullo, L. Clinical outcome study of customized zirconia abutments for single-implant restorations. Internat. Jour. of Prosth.(2007) 20: 489-493.

8. Andersson B1, Taylor A, Lang BR, Scheller H, Schärer P, Sorensen JA, Tarnow D Alumina ceramic implant abutments used for single-tooth replacement: a prospective 1- to 3-year multicenter study. Int J Prosthodont. 2001 Sep-Oct;14(5):432-8.

9. Park, S.E., Da Silva, J.D., Weber, H.P. \& Ishikawa-Nagai, S. Optical phenomenon of periimplant soft tissue. Part I. Spectrophotometric assessment of natural tooth gingiva and periimplant mucosa. Cl.Oral Impl.Res. (2007) 18: 569-574.

10. Lops, D., Bressan, E., Chiapasco, M., Rossi, A. \& Romeo, E. (2013) Zirconia and titanium implant abutments for single-tooth implant prostheses after 5 years of function in posterior regions. Int.Jour. of Oral \& Max. Implants 28: 281-287.

11. Zembic, A., Bosch, A., Jung, R.E., Hammerle, C.H. \& Sailer, I. (2013) Five-year results of a randomized controlled clinical trial comparing zirconia and titanium abutments supporting single-implant crowns in canine and posterior regions. Cl.Oral Impl. Res. 24: 384-390. 
12. de Alboroz, C.A., Vignoletti, F., Ferrantino, L., Cardenas, E., De, S.M. \& Sanz, M. (2014) A randomized trial on the aesthetic outcomes of implant-supported restorations with zirconia or titanium abutments. Jour.of Clin. Period. 41: 1161-1169.

13. Follmann D, Elliott P, Suh I, Cutler J. Variance imputation for overviews of clinical trials with continuous response. Jour.of Clin. Epid. 1992;45(7):769-73.

14. Lops, D., Bressan, E., Parpaiola, A., Luca, S., Cecchinato, D. \& Romeo, E. Soft tissues stability of cad-cam and stock abutments in anterior regions: 2-year prospective multicentric cohort study. Clin Oral Implants Res. 2015 Dec;26(12):1436-42.

15. Nascimento Cássio do, Murillo Sucena Pita, Emerson de Souza Santos, Nadia Monesi, Ricardo Faria Ribeiro Microbiome of titanium and zirconia dental implants abutments .Dental Materials, 32, 1, 2016, Pages 93-101

16. Yogesh V, Jain V, Chauhan SS, Bharate V, Koli D, Kumar M. Influence of different forms and materials (zirconia or titanium) of abutments in peri-implant soft-tissue healing using matrix metalloproteinase-8: A randomized pilot study. J Prosthet Dent. 2017 Oct;118(4):475-480

17. Sailer, I., Zembic, A., Jung, R.E., Siegenthaler, D., Holderegger, C. \& Hammerle, C.H. Randomized controlled clinical trial of customized zirconia and titanium implant abutments for canine and posterior single-tooth implant reconstructions: preliminary results at 1 year of function. Cl.Oral Impl.Res. (2009) 20: 219-225.

18. Zembic, A., Sailer, I., Jung, R.E. \& Hammerle, C.H. Randomized-controlled clinical trial of customized zirconia and titanium implant abutments for single-tooth implants in canine and posterior regions: 3-year results. Clin.Oral Impl. Res. (2009) 20: 802-808.

19. Zembic, A., Philipp, A.O., Hammerle, C.H., Wohlwend, A. \& Sailer, I. Eleven-year followup of a prospective study of zirconia implant abutments supporting single all-ceramic crowns in anterior and premolar regions. Clin Implant Dent Relat Res. 2015 Oct;17 Suppl 2:e417-26. doi: 10.1111/cid.12263.

20. Linkevicius, T. \& Apse, P. Influence of abutment material on stability of peri-implant tissues: a systematic review. The Inter. Jour.of Oral \& Maxill.Implants (2008) 23: 449-456.

21. van Brakel, R., Noordmans, H.J., Frenken, J., de Roode, R., de Wit, G.C. \& Cune, M.S. The effect of zirconia and titanium implant abutments on light reflection of the supporting soft tissues. Clin.Oral Impl. Res. (2011) 22: 1172-1178.

22. Nothdurft, F.P., Fontana, D., Ruppenthal, S., May, A., Aktas, C., Mehraein, Y., Lipp, P. \& Kaestner, L. (2014) Differential behavior of fibroblasts and epithelial cells on structured implant abutment materials: a comparison of materials and surface topographies. Clin Implant Dent Relat Res. 2015 Dec;17(6):1237-49.

23. Hosseini, M., Worsaae, N., Schiodt, M. \& Gotfredsen, K. A 1-year randomised controlled trial comparing zirconia versus metal-ceramic implant supported single-tooth restorations. Europ. Jour. of Oral Impl. (2011) 4: $347-361$.

24. Hosseini, M., Worsaae, N., Schiodt, M. \& Gotfredsen, K. A 3-year prospective study of implant-supported, single-tooth restorations of all-ceramic and metal-ceramic materials in patients with tooth agenesis. Clin. Oral Impl. Research (2013) 24: 1078-1087.

25. Gapski, R., Neugeboren, N., Pomeranz, A.Z. \& Reissner, M.W. Endosseous implant failure influenced by crown cementation: a clinical case report. The International Journal of Oral \& Maxillofacial Implants (2008) 23: 943-946.

26. Wilson, T.G., Jr. The positive relationship between excess cement and peri-implant disease: a prospective clinical endoscopic study. Journal of Periodontology (2009) 80: 1388-1392.

27. Linkevicius, T., Vindasiute, E., Puisys, A. \& Peciuliene, V. The influence of margin location on the amount of undetected cement excess after delivery of cement-retained implant restorations. Clinical Oral Implants Research (2011) 22: 1379-1384.

28. Balasubramaniam GR. Predictability of resin bonded bridges - a systematic review. Br Dent J. 2017 Jun 9;222(11):849-858.

29. Mascarenhas F, Yilmaz B, McGlumphy E, Clelland N, Seidt J. Load to failure of different zirconia implant abutments with titanium components. J Prosthet Dent. 2017 Jun;117(6):749-754.

30. Ralph V, Cune MS, van Winkelhoff AJ, de Putter C, Verhoeven JW, van der Reijden W. Early bacterial colonization and soft tissue health around zirconia and titanium abutments: an in vivo study in man. Clin Oral Implants Res. 2011 Jun;22(6):571-7.

31. Belser, U.C., Schmid, B., Higginbottom, F. \& Buser, D. Outcome analysis of implant restorations located in the anterior maxilla: A review of the recent literature. International Journal of Oral and Maxillofacial Implants (2004) 19 (Suppl.): 30-42.

32. Buchi, D.L.E., Sailer, I., Fehmer, V., Hammerle, C.H.F. \& Thoma, D.S. (2014) All-ceramic singletooth implant reconstructions using modified zirconia abutments: a prospective randomized controlled clinical trial of the 
effect of pink veneering ceramic on the esthetic outcome. The International Journal of Periodontics \& Restorative Dentistry 34: 29-37.

33. Bra"gger, U., Karoussis, I., Persson, R., Pjetursson, B., Salvi, G. \& Lang, N.P. (2005) Technical and biological complications/ failures with single crowns and fixed partial dentures in implants: a 10-year prospective cohort study. Clinical Oral Implants Research 16: 326-334.

34. De Boever, A.L., Keersmaekers, K., Vanmaele, G., Kerschbaum, T., Theuniers, G. \& De Boever, J.A. (2006) Prosthetic complications in fixed endosseous implant-borne reconstructions after an observation period of at least 40 months. Journal of Oral Rehabilitation 33: 833-839.

35. Ekfeldt, A., Furst, B. \& Carlsson, G.E. (2011) Zirconia abutments for single-tooth implant restorations: a retrospective and clinical follow-up study. Clinical Oral Implant Research 22: 1308-1314.

36. Nakamura, K., Kanno, T., Milleding, P. \& Ortengren, U. Zirconia as a dental implant abutment material: a systematic review. The International Journal of Prosthodontics(2010) 23: 299-309.

37. Muche, R., Krausse, A. \& Strub, J.R. Success rates of implant supported prostheses in partially edentulous patients - part ii. Schweizerische Monatsschrift fu"r Zahnmedizin (2003) 113: 404-410.

38. Passos, S.P., Linke, B., Larjava, H. \& French, D. Performance of zirconia abutments for implant-supported single-tooth crowns in esthetic areas: a retrospective study up to 12-year followup. Clinical Oral Implants Research, (2014) doi:10.1111/clr.12504.

39. Pjetursson, B.E., Tan, K., Lang, N.P., Bra"gger, U., Egger, M. \& Zwahlen, M. (2004) A systematic review of the survival and complication rates of fixed partial dentures (FPDs) after an observation period of at least 5 years. Int J Dent. 2012; Nov 4. doi: 10.1155/2012/876023

40. Sailer, I., Philipp, A., Zembic, A., Pjetursson, B.E., Hammerle, C.H. \& Zwahlen, M. (2009) A systematic review of the performance of ceramic and metal implant abutments supporting fixed implant reconstructions. Clinical Oral Implants Research 2009(Suppl. 4): 4-31.

41. Vigolo, P., Givani, A., Majzoub, Z. \& Cordioli, G. A 4-year prospective study to assess periimplant hard and soft tissues adjacent to titanium versus gold-alloy abutments in cemented single implant crowns. Journal of Prosthodontics(2006) 15: 250-256. 